\title{
AECD $-39 / 8$
}

CLImos BNoIxas: wORKA

TEMBSSSES BASTEN CORFORT T10

Contreot No, \#-7401-ang-23

\section{A PILOT PLAMT}

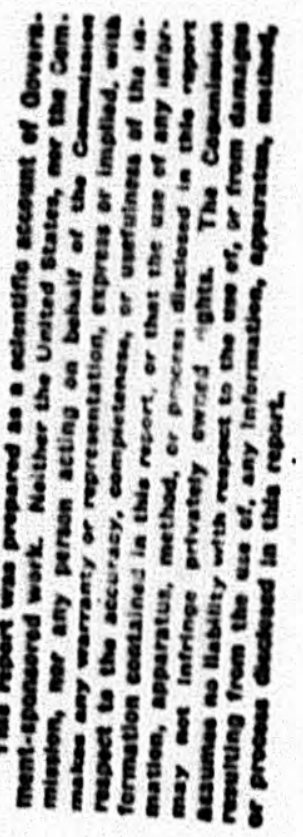

POH THE YISPARATION OF UKAKIUA TETRACHLORIDE

\author{
BY FLUIJI2:TION
}

\section{ABjTKACT}

A pilot plant for the proparation of urenium totrachlorido by fluldization from uranium $t$ ri oxldo was dosigned, constructod and tostod. Batohes oonsisting of 100 erams of $50-200$ (U.S. number) mosh oxido wore convertod in 50-minuto roaction poriods to totrachloride of excollont toxture, $98,0 \%$ chlorinated, $97.0 \%$ imnodiatoly available os product. The Rluidizer oontalnod no movosble parts and was mochenically oasy to hendlo.

Photostat Price

Microfilm Price s 3.30

Available from the

Office of Techinical Services

Department of Commerce

Washington 25, D.C.

Subanittod, March 12, 1946. 


\section{$\vdots$}

\section{A PILOT PLANT \\ FOR THE PRESARATION OF URANIUM TETRACHLORTOS \\ BY FLUDIZATION}

\section{SULEARY}

A pilot plant for the preparation of uranium tetrachlorido by Ruidization from uranium trioxide was designed, constructed, and tested. Datches consisting of 100 grams of 50 to 200 (U.S, number) wesh, bulk tratment oxide were converted in 50-minute reaction periods to tetrachloride of excellent texture, 98.86 chlorinated, 97.06 avallablo imodiately as product.

Chlorination was accomplished with carbon tetrachloride vapors, dilutad with dry nitrogen during the initial stages of reaction. The temperature of the gas was $320^{\circ} \mathrm{C}$; that of the solids was variod between $280^{\circ}$ and $420^{\circ} \mathrm{C}$ during chlorination. About $250 \mathrm{cc}$ of carbon tetrachloride was necessary for complete conversion of 100 grams of oxide.

Two types of equipment rere tested and the system that proved superior was employed in obtaining the results listed above. It consisted of: a nickel reaction chamber conical in shape, 35 inches in hoight, is inches in diameter at the top, 1 inch at tho base; a nickel loating unit fastened to the base of the cone, 1 inch in dianeter, 12 inches high, tapering down to a 1/8 inch gas inlet pipe at its base; a pot to vaporize carbon tetrachloride; and condensers to trap excess vapors.

A series of experiments utilizing puro carbon tetrachioride vapors rasulted in caking and partial fusion of the product. Dilution of the gas with dry nitrogen during the initial stages of reaction facilitated the proper dissipation of heat and yielded a product of excellent texture. About 


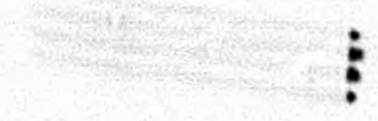

Lot (by volumo) nitrogen dilution was cemployed during the first 8 minutes of reaction, 200 during the second, and pure carbon tatrachloride during the reanining 34 minutes.

An inftial somperature of $280^{\circ} \mathrm{C}$ was found hiph onough to start renction yet sufficientiy lon to provent the heat of chlorination from calding the solids. A final temperature of about lo00 was necessary to complete chlorination within a period of 50 minutes.

Varlous particle size ranges were tested and a maximum yield of avajlable product, $97.0 \%$, was obtainod with 50-200 mesh (U,S, number) oxide. Nost of the material that was not renoved as product, adhorod to the walls of the cone. The remainder was entralned in the gas stroar and trapped in tix condensers at the outlet of the system.

It was thought that an increase in the range of particle size employed, and the yleld of avallable product could be effected by incrousing the diameter ratio of the reaction chamber, and the size of the charge.

\section{INTRODUCTION}

Proliminary exporimental work on the preparation of uranium tetrachloride by a Muidization technique has been described in Report 0.5 .350 .3 , Series A. A laboratory procedure had been developed wherein unactivated Malinckrodt uraniun trioxide was converted into a good grado of tetrachlorido in a period of 20 minutes, using carbon tetrachloride vapors at $240^{\circ}$ to $280^{\circ} \mathrm{C}$. On the basis of these results 1 was determined to carry out further work on a pilot plant scale of operations.

The principle involved in the "Muidization" technique is the suspension of a vertical bed of solid particles in a stream of gas passing . upward through the bed, setting each particle into violent turbalent wotion, 
A large surface area is thereby exposed and tne desired reaction greatly facilitated.

It was belioved that a fuidization process would yleld a product of good texture and quality with a minimum of equipment and mochaniosl difficulty.

\section{APPARATUS}

\section{Ruidization System I, Migure I}

The first fuidization systea constructed and tested consisted of the following:

A. A nickel, stom-jacket, pot for the vaporization of carbon tetrachloride.

B. An orifice with valives on either side for the regulation of vapor now.

c. A the before the orifice to permit nitrogen difution of the vapors.

D. Six feet of $1 / 2$ inch stainless steel pipe wrapped with nichrome wire, and 6 feet of $1 / 8$ inch pipe inside the rurnace for the purpose of superheating the carbon totrachloride vapors.

E. A nickel cone, 4 inches in diameter at the top, 1 inch at the base, and 40 inches in height placed inside a furnace.

F. A I inch valve at $t$ he base of the cons for unioading product.

Q. A toe at the top for loading charge.

H. A condenser and liquid trap for excess carbon tetrachloride vapors.'

\section{Fluidization System II, FIgure II}

Based on the difficulties encountered in the first system, a socond was designed, constructed and tested. It consisted of the following: 
A. A nickel, otean jeckoted pot for the vaporizetion of carbon tetrechloride.

B. An orifice with valves on either oide for the regulation of vapor now.

C. A toe before the orifice to permit nitrogen dilution of the vapors.

D. A difforential now manometor, and a static pressure manomotor to dotoct plugging of the vapor lines.

F. Six foet of $1 / 2$ inch stainless oteel pipe wrapped with nichrome heating wire to superheat the carbon totrachloride vapors.

F. A 35-inch nickel cone, 4 inches in dianeter at tho top and 1 Inch at the baso.

O. A detachable loading unit: 1 inch in diameter, 18 inches high, tapering dom to a $1 / 8$ inch V-tube; flanged at the top to attach to the cone; and supplied with a union at the end of the v-tube to connect to the vapor line-- all made of nickel and wrapped with nichrome wire.

H. A glasa head Ranged to fit anto the top of the cone.

I. Two plass eondensers and a liquid trap to catch excess carbon tetrachloride.

\section{PROCFDURE}

\section{Fuidisation Systom I, Figure I}

The first Ruidization systen was operated as follows:

A. Carbon totrachloride was loaded into the vaporizer and low pressure stoam admitted into the steam jacket.

B. The furnace and nichrome heating jacket wore turned on.

C. A charge of uranium trioxide was loaded into the top of the reactor by means of a funnel. 
D. The valve past the orifice was opened wide while the valve betwoen orifice and vaporiser was used to regulate flow. The differential now manoweter faeilitated the roproduction of now rates.

8. After the reaction period, the two now val ves rere shut and the val ve at the base of the cone opened to unlosd product.

\section{nuidisation Syston II, Figure II}

The second Rusdisation system was operated as follows:

A. Carbon tetrachloride was loaded into the vaporizer and low prossure stoan adnitted into the jacket.

B. The rurnace and gas heating jackot wero turned on.

C. Bulk treatment uranium trioxide, previously sieved for 20 minutes to the proper mesh by means of a Ro-Tap and then calcined for 3 to 4 hours, was used as starting waterial. The loading unit was charged with a weighed quantity of the oxide; attached to the bottom of the cone and to the vapor IIne; and then the nichrome heating jackot turned on.

D. The valve past the orifice was opened and a rotameter-Heasured now of dry nitrogen admitted into the system at the toe before the orifice.

5. The valve immediately above the vaporizer was opened to a position that gave a specified reading on the differential orifice manometor.

P. Temperature readings vere taken at the loading unit (see Pigure II), at the gas Iine immediately before the loading unit, and in the furnece surrounding the cone.

0. Differential and downstream static pressures ware taken at the orifice.

15. At the end of a run the two flow valves were shut, the heating

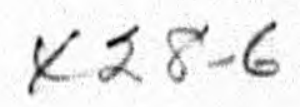


jacket on the loading unit turned off, and the loading unit detachod and overturned to obtain the product.

\section{RESULTS}

\section{Ruidization Syatom I, Plaure I.}

The original fluidization system was found to be machanically unsatisfactory:

A. The valve st the base of the cone did not operate properly after several runs. Particles of oxide worked their way into the machanism and prevented proper closing.

B. The construction of the unit was such as to expose several threaded soctions inside the reaction zone. These threaded sections offered settling surfaces to the solid particles and therby caused hold-up and incomplete reaction.

C. The gas inlet pipe extending down the length of the inside of the cone interfered inth proper flutdization.

D. The rectangular shape of the section inmediately above the unloading valve caused the presence of unreacted oxide, and occasionally unreacted lumps in the product.

Fuidization System II, Figure II

Design Experimonts - Preliminary experiments on the second fluidi 2 ation system were made with a glass loading unit of the same design as the one pictured in Figure I. The results were excellent. Oxide particles were absent from the product, and operation was smooth and simple.

It was observed that most of the charge remained nuidized in the loading unit itself. The cone operated os a trap for fing particles and very little material was carried over into tho glass condenser systom. 
The Texture Problem -- A metal losding unit of the same design as the glass apparatus was constructed and tested. The first problem oncountered was the caking of the solid material, tho consequent improper fluidization and incomplete chlorination. The solution of this problem was accoraplished by diluting the carbon tatrachloride vapors with dry nitrogen during the initial stages of reaction, combined with careful control of now rates.

Temperatures measured at the loading unit thermocouple indicated that, the reaction initiated at $250^{\circ} \mathrm{C}$ and became rapid at $280^{\circ} \mathrm{C}$. \#ithout nitro gen dilution, temperatures rose uncontrolably during the first fow minutes of chlorination and resulted in caking of the product. Tith dilution of the vapor, however, it was found possible to control the initial temperature rise and produce a product of good texture, free of cakes or lumps (see Table I.)

The Problem of Complete Chlorination - After determining a method for producing material of good texture, succeeding experiments were directed toirard the production of good quality tetrachloride; 1.e. completely chlorinated. Runs $\mathrm{N}$-111 through $\mathrm{J}-117$ ylelded an average of 98.96 chlorinated material of excellent texture (see Table I).

The Problem of Available Product - The next series of runs were made with the object of obtaining a maximum yield of available product. An average yield of $97.0 \%$ was obtained with 50 to 200 (U.S. number) mesh oxide (see Table II and III).

Track Tests - Track tests vere made utilizing material from Runs $202,203,205,212$ and 216. The charge behaved properiy and was reported as "good" by XBX. 


\section{TABLS I}

Ail rume mare made with 100 rren charges of Bulk Treatmont uranilum trioxido, 20 to 60 (U.S. number) mosh. The everace juantity of carbon totrachlorido employod for oech run was $250 \mathrm{co}$, veporizod in an avorage of 50 minutes. Gaupe pressure for all runs was 3 ens of moroury.

\begin{tabular}{|c|c|c|c|c|c|c|c|c|c|}
\hline $\begin{array}{l}\text { Run lo. } \\
\text { (s⿱s) }\end{array}$ & $\begin{array}{l}\text { Ges Tomp. } \\
\left(\mathrm{O}^{\mathrm{C}}\right)^{-}\end{array}$ & $\begin{array}{l}\text { solida Tomp. } \\
\text { (o }{ }^{\circ} \text { ) } \\
\text { (londing unit } \\
\text { thormocouplo) }\end{array}$ & $\begin{array}{l}\text { Nitrogen } \\
\text { t by vol. }\end{array}$ & $\begin{array}{l}\text { Plginge } \\
\text { (min.) }\end{array}$ & $\begin{array}{c}\text { Tota) } \\
\text { Sosction } \\
\text { Time } \\
(\min ) \\
\end{array}$ & $\begin{array}{l}\text { Toxture } \\
\text { of } \\
\text { Product }\end{array}$ & $\begin{array}{c}\text { Porcort } \\
\text { innolublos } \\
\text { in protuct } \\
\end{array}$ & $\begin{array}{l}\text { Mo: Matto } \\
\mathrm{SCl} / \leq U\end{array}$ & $\begin{array}{c}\text { Porcont } \\
\text { Chlorimation }\end{array}$ \\
\hline 111 & 332 & 283 to 397 & $\begin{array}{r}40 \\
20 \\
0\end{array}$ & $\begin{array}{r}7 \\
8 \\
34\end{array}$ & 45 & exeollent & $\cdots$ & 1.00 & 100.0 \\
\hline 112 & 325 & 290 to 430 & $\begin{array}{r}40 \\
20 \\
0\end{array}$ & $\begin{array}{r}6 \\
6 \\
30\end{array}$ & 42 & sxeellent & 0.52 & 3.94 & 98.6 \\
\hline 113 & 321 & 320 to 420 & $\begin{array}{r}40 \\
20 \\
0\end{array}$ & $\begin{array}{r}8 \\
6 \\
35\end{array}$ & 49 & oxcollent & $\cdots$ & 3.92 & 98.0 \\
\hline 114 & 31) & 280 to 425 & $\begin{array}{r}40 \\
20 \\
0\end{array}$ & $\begin{array}{r}4 \\
41\end{array}$ & 51 & excellient & 1.57 & 3.97 & 99.3 \\
\hline 115 & 318 & 280 to 413 & $\begin{array}{r}25 \\
20 \\
0\end{array}$ & $\begin{array}{r}10 \\
9 \\
45\end{array}$ & 64 & oxcollont & 0.80 & 3.94 & 98.5 \\
\hline 116 & 318 & 280 to 112 & $\begin{array}{r}25 \\
20 \\
0\end{array}$ & $\begin{array}{r}6 \\
9 \\
47\end{array}$ & 62 & oxcollent & 0.54 & 3.13 & 98.3 \\
\hline 117 & 328 & 295 to 440 & $\begin{array}{r}40 \\
0\end{array}$ & 33 & 37 & oxcollont & 0.85 & 3.95 & 98.8 \\
\hline
\end{tabular}




\section{$\vdots$}

\section{TABLS II}

The oharte omployed in all runs was $100 \mathrm{grang}$ of 50 to $200 \mathrm{mesh}$ (U.s. number) Bulk Trsatment uranium trioxido. The toxturo of the product was in all casos oxcollont, and wator solubility toats indicatod the quality of the product to be oxcellont in all runs.

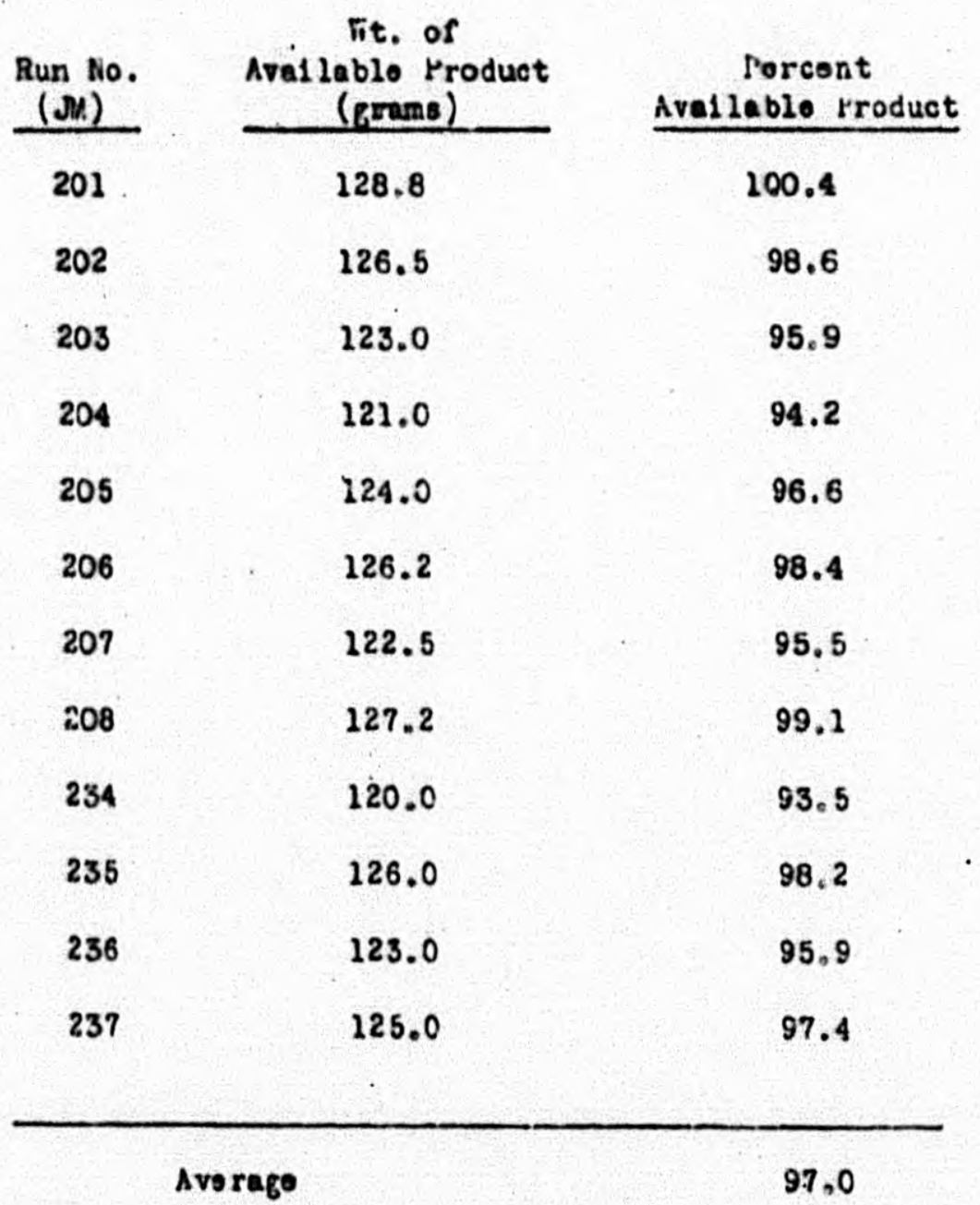

Note: Yiold calculations vere mede on tho besis of an avorace analysis (four samples) of $79.9 \%$ uranlum in the Bulk Treatmont charge matorial, and an avorago of $62.3 \%$ urani um in the product of Runs $\pi / 11$ ? through JN 117218 tod in Tablo 1 . 


\section{TABLE III}

The chargo omployed in oll runs was 100 grams of Bulk Troetment oxide. The texture of the produot was in all ceses oxcollent, and wator solubility tosts indioetsd the quality of the product to bo oxcollent in all runs. Yleld calculations wir) made on the sane beses as those in Toblo II.

\begin{tabular}{|c|c|c|}
\hline $\begin{array}{l}\text { Number } \\
\text { of Runs } \\
\end{array}$ & $\begin{array}{c}\text { Ho sh } \\
\text { (0.3. Numbor) } \\
\end{array}$ & $\begin{array}{c}\text { Average Yiold of } \\
\text { available product } \\
\text { (porcont) }\end{array}$ \\
\hline 8 & 20 to 50 & 90.6 \\
\hline 17 & 50 to 100 & 95,5 \\
\hline 6 & 50 to 140 & 95.9 \\
\hline 12 & 50 to 200 & 97.0 \\
\hline 4 & $<50$ & 91.7 \\
\hline
\end{tabular}

\section{TABLE IV}

The following are the rosulte of a scroen analysis conducted by D. C. Schumacher on Bulk Troatrent uranium trioxido, July $10,1945$.

\begin{tabular}{|c|c|c|c|}
\hline & $\begin{array}{c}\text { Screan S120 } \\
\text { (nas ah) }\end{array}$ & $\begin{array}{c}\text { Particlo Size } \\
\text { (Inchos) }\end{array}$ & $\begin{array}{l}\text { Perosnt } \\
\text { (by } \approx t) \\
\end{array}$ \\
\hline & on 28 & 0.0232 & 17.2 \\
\hline & 48 & 0.0116 & 30,4 \\
\hline & 60 & 0.0098 & 8.6 \\
\hline & 80 & 0.0070 & 10.2 \\
\hline & 100 & 0.0059 & 6.2 \\
\hline & 200 & 0.0029 & 12,6 \\
\hline through & 200 & 0,0029 & 14.4 \\
\hline
\end{tabular}




\section{DISCUSSION OF RESULTS}

\section{Fuidization System I, Flgure I}

Moveable Parto - Fine fuidized particles penetrated the intermost portions of the valve that was employed in the first a ttempt at pilot plant operation. It was concluded that valves, or noveabie parts of any kind more to be avolded in the design of Muidization equipment.

Irregular Surfeces -- Threaded sections exposed interneily in the conical reactor were found to form excellent settling surfaces for oxide particles. Material caked and settled on all irregular surfaces causing poor fluidization and a lack of uniformity in the product. For efficient operation it was considered that smooth internal surfaces were necessary.

Internal Downward Gas Peed - The downward gas feed did not always Ruidize material between the Inlet and base of the cone, causing some oxide to remain caked and unreacted. Then also tho long internal gas inlet p1pe added further surface for adhesion. The system was, therefore, found unsatisfactory. It is, however, conceivable that is can be employed successfully with improved design and accurate construction.

Rectangular Sections -- The section of reactor Immediately above the unloading valve was alnost rectangular in shape, the closed valve being horizontal and the walls of the cone almost vertical. Unreacted oxide was invariably found in the corners of this section. It was, therefore, determined to avoid rectanguiar sections therever posisible.

Muidization System II, Figure II

Desien Exporiments - The second fluidisation system, omploying a loading unit in place of a valve, proved satisfactory. The $\mathrm{V}$-bend in the Inlet gas line prevented solids from backing into the vapor system. The 
gradual taper of the gas line leading up to. the 1-inch section o: the loading unit eliminated corners and avoided the accumulation of oxide particles.

It was observed that most, of the charge rexrained fluidized in the loading unit, the cone acting primarily as a trap for the finer particles. Therefore, the temperature most indicative of the progress of reaction was the one taken at the loading unit thermocouple, while the temperature of the cone remained relatively unimportant.

The Texture Problem -- From observations on the original glass experimental apparatus (see Report $\mathrm{C}-5,350,3$, Serles A), it was concluded that caking was caused by localized accumulation of heat. The formation of the tetrachloride from $\mathrm{UJ}_{3}$ and $\mathrm{CCl}_{4}$ is an exothernic resction and when 1 t proceeds rapidly without proper dissipation of the heat of formation, caking and occasionally even fusion occurs. The dilution of the vapor stream with dry nitrogen reduced the caking tendency in two ways, It decreased the rate of reaction by reducing the concentration of carbon tetrachloride, and facilitated the removal of excess heat by addition of a volume of inert gas. Reaction was found to proceed very rapidly during the first seven or eipht minutes-a peak temperature often being reached four minutes after the start of chlorination. The greatest danger of caking or fusion occurs during this period since the largest part of the chlorination and heat 11beration take place. Thereafter caking occurs infrequently and solid temperatures can be raised to as high as $440^{\circ} \mathrm{C}$ with 11 ttle danger. The procedure that vas developec, however, provided for two stages of dilution lasting about 16 minutes (see table I, Results) to insure the production of good totrachloride.

Actual operation of the system reveals that caking difficultios

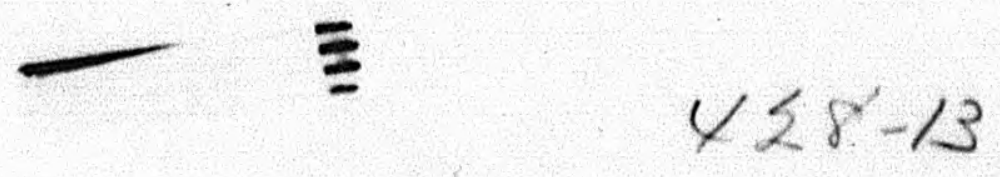




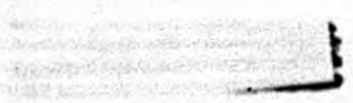

are imediately discermable on the static pressure manometer. During normal operation the static pressure remains fairly constant. As soon as a cake develops, however, the pressure changes radically. It either drops due to channeling of the gases or rises sharply because of the forwation of a pluß. Upon observing such a condition the reaction can be stopped without Turther raste of time.

\section{The Problen of Complete Chlorination - The production of ana-}

lytically good tetrechloride was primarily a problem in schisving the last few percent of chlorination. Over 808 of the chlorination was accomplished in the first 10 minutes of reaction, and not all of the remaining 40 minutes was absolutely necessary but was considered advisable in the development of a safe standard procedure.

The Problem of Avallable Product - The available product calculations (Tables II and III) were based on an average of 4 analyses of charge material showing 79.9 percent uranium in the oxide, and an average of 62.3 percent uranium in the product of Runs 111 through 117 (in Table I). Tho rleld figures are, therefore, not perfectly accurate since product analyses were not made on the runs that were actually used to calculate ylelds. The Inaccuracy, however, is on the conservative aide. Runs 111 through 117 produced material that was, on the average, 98.8 percent chlorinated. If the products of the yield runs were not of similar quility, the uranium content would be greater than 62.3 percent, and the yields, therefore, larger than those 11sted.

The procedures of operation were similar throughout. Any variation in the quality of product could only have been caused by variation in the particle size of the charge material. The product, however, was 
:

oonstantiy checked by wator solubility toste, in which the oporators achioved a high dogroo of proficioncy.

Tablo III Indicatos that thero oxf sto a range of particlo ifeo Which produces a maximum of avallable product. 20 to 50 mosh (U.S. number) and 50 mosh material, tho two oxtromes in partiole sieo rango, both gavo much lowor ylolds than the intermodiato ranges.

It is bolloved that tho larger particles in volont agitation and subject to constant abrasion, break down into fino matorial which is ontrainod in tho gas otream. Snaller particles, on the other hand, requiro a lower veloelty for fluidization and the fines that they produce are not as onsily ontralnod. The emellost range ( $>200$ mosh), howgvor, may contain a quantity of matorlal which has proctically no sottling volool ty and cannot avoid ontrainment.

Lareor sizo partioles not employed in reaction wore onsily ground to propor alzo. It was also found poseible to make use of the fines. They agelomerated upon moistoning and were, thereaftor, also ground to proper a120.

The operating range onn undoubtedly be increseed in both dirootions (from 50 to 200) by tho installation of a croetor diametor ratio in the reaction cone. More officiont trapping of the fines in such a unit would increase the yield of available product.

\section{RZVIEM AND RECONSNDATIOES}

The fluidization tochnique of totrachlori de production ylolded 98.8\% chlorinated matoriel in a poriod of 50 minutes, 97.05 evaialble Inmodiatoly as product. The oquipnent contained no movenble parts and was mocharically oasily handlot 
The runge of particle s1ze employed in the charge was 50 to 200 mesh (v.S. numbor). It is bolleved that this range can be incruased by the construetion of a cone with larger then a 4 to 1 diameter ratio.

It is furtherwore belleved edvisable that exporiments bo made to deterratne the overall zosses from the system, and efforts be made to further increase ylolde of avallable product.

$\mathrm{HAF} / \mathrm{ah}$

21. Q. Peilmutter

Date Subalttod: Warch 12, 1946
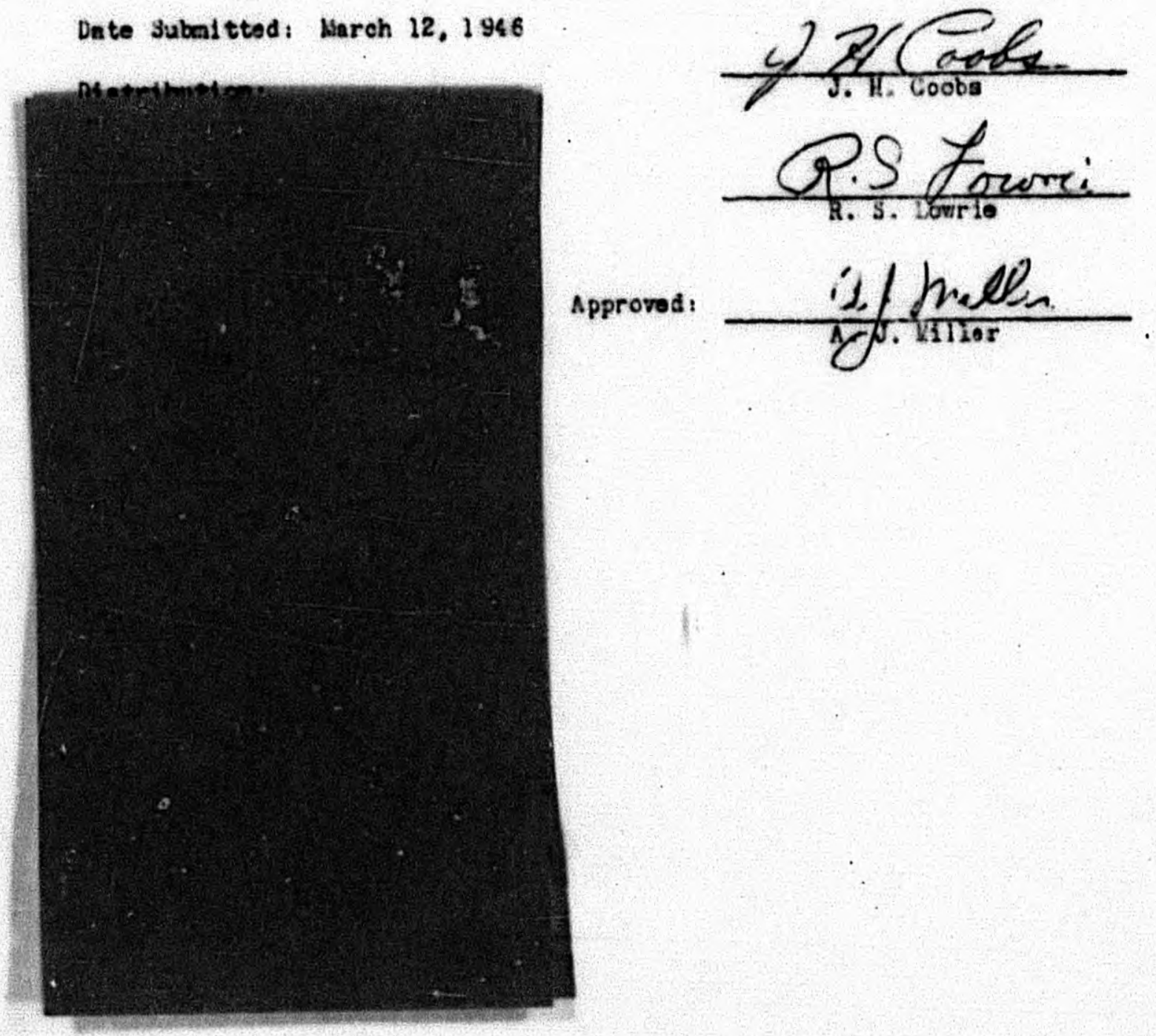

Approved:

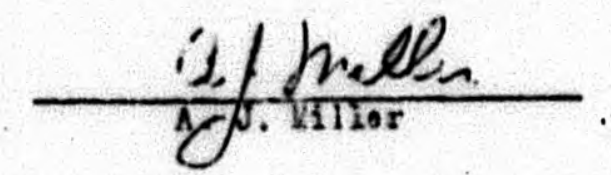







